\title{
Perancangan mesin penghancur sekam padi dengan poros penggerak horizontal
}

\author{
Ahmad Suudi, Novri Tanti, Jamiatul Akmal, Zulhendri Hasymi, Prasetyo Budiyanto
}

Program Sarjana Jurusan Teknik Mesin, Universitas Lampung J1. Prof. Dr. Sumantri Brojonegoro No. 1 Bandar Lampung, 35145

Email korespondensi:

\begin{abstract}
Abstrak
Sekam adalah limbah dari proses penghancuran, memiliki sifat yang keras, bersisik dan kering. Pada proses penggilingan padi, berdasarkan Badan Pengembangan dan Penelitian Pertanian, Departemen Pertanian mendapatkan 20-30\% sekam padi, 8-12\% kulit padi dan 50-63,5\% padi gilingan. Dapat diperhatikan bahwa sebagian besar jumlah limbah didominasi oleh sekam padi dan jika tidak segera ditangani akan berpengaruh buruk pada lingkungan. Usaha yang dapat dilakukan untuk mengurangi limbah yakni dengan membuat inovasi agar mesin penghancur dapat mengolahnya menjadi serbuk. Metode implementasi bermula dengan perancangan, pembuatan dan pengujian. Mesin penghancur akan dirancang agar dapat dilengkapi dengan mesin bensin, menggunakan transmisi $V$ belt dan jenis grinder dengan kombinasi discmill dan hammermill. Hasil dari kajian dan desain ini adalah mesin penghancur sekam padi dengan dimensi yakni tinggi $1100 \mathrm{~mm}$, panjang $400 \mathrm{~mm}$, dan lebar $500 \mathrm{~mm}$, mesin bensi Hyundai HDE 390 dengan daya 7,6 kW, elbow profile frame dengan dimensi 50 mm 50 mm, transmisi sabuk dan puli dengan rasio 1:1, kombinasi mekanisme penggilingan bernama hammermill yang memiliki 3 hammer tunggal dan penghancur yang dilengkapi dengan conveyor baut. Hasil pengujian dari mesin penghancur yakni menghasilkan kapasitas 10 kg/jam, dan komsumsi bahan bakar sebanyak 2,162 liter/jam.
\end{abstract}

Kata kunci: sekam padi, mesin gerinda, penggiling padi.

\begin{abstract}
Husk is a waste from the grinding process with the characteristics of a hard, scaly and dry layer. In the rice milling process, according to the Agricultural Research and Development Agency, the Department of Agriculture obtained 20-30\% of rice husk, 8-12\% of bran and $50-63.5 \%$ of milled rice. It can be seen that the amount of waste produced is predominantly dominated by rice husk and if not handled it will be a problem for the environment. One effort to reduce the form of waste was carried out research design of rice husk grinding machine become powder. The implementation method starts with designing, manufacturing and testing. The design of the grinding machine is planned to use a fuel motor drive, the transmission uses a $V$ belt and the type of grinder is a combination of discmill and hammermill.The results of research and design obtained rice husk grinding machine with specifications dimensions of $1100 \mathrm{~mm}$ high, $400 \mathrm{~mm}$ long and $500 \mathrm{~mm}$ wide, Hyundai gasoline engine drive HDE 390 with power $7.6 \mathrm{~kW}$, elbow profile frame $50 \mathrm{~mm} \times 50 \mathrm{~mm}$, belt transmission and pulley with a ratio of 1: 1, a combination milling mechanism namely hammer mills which have 3 single hammer attrition mills and a front through grinder with the help of screw conveyor components. The test results of the grinding machine capacity obtained a production capacity of $10 \mathrm{~kg} /$ hour, and fuel consumption which is 2.162 liters / hour.
\end{abstract}

Keywords: rice husk, grinding machine, hammer mills, disc mills.

\section{Pendahuluan}

Tanaman padi merupakan tanaman budidaya utama di Indonesia yang menghasilkan beras untuk bahan pangan pokok mayoritas masyarakat Indonesia, dengan nilai konsumsi peringkat pertama terbanyak dari bahan makanan pokok lainnya. Menurut Badan Pusat Statistik (BPS) Indonesia, data produksi padi meningkat tiap tahunnya dan pada tahun 2015 Indonesia memproduksi padi sebanyak 75.397.841 ton. Padi yang dihasilkan pasca panen tersebut akan melalui beberapa tahap lagi untuk menghasilkan beras yang siap untuk dijual. Salah satu proses yang mengalami banyak kehilangan yaitu proses penggilingan padi untuk menjadi beras [1]. Menurut Kementerian Pertanian Direktorat Jendral Tanaman Pangan jumlah padi yang diproses menjadi beras mengalami penyusutan sebanyak $62,74 \%$ atau sekitar 47.304.605 ton, dan sisanya yaitu sekitar 28.093.236 ton adalah produk sampingan yang sering disebut dengan limbah [2].

Limbah pada umumnya adalah produk yang memiliki nilai ekonomi yang sangat kecil sehingga banyak limbah hasil penggilingan tersebut hanya terbuang sia-sia. Pada proses penggilingan padi, menurut Badan Penelitian dan Pengembangan Pertanian, Kementrian Pertanian Republik Indonesia didapat 20$30 \%$ sekam padi, $8-12 \%$ dedak dan 50-63,5 \% beras giling. Selain dengan jumlah beras sebagai produk yang diinginkan tersebut, jumlah limbah yang dihasilkan mayoritas didominasi oleh sekam padi 
Pada proses penguraiannya secara alami, sekam padi akan sulit untuk diurai dalam waktu singkat sehingga limbah tersebut dapat mengganggu ekosistem di lingkungannya [2]. Pada saat ini pemanfaatan secara sederhana limbah sekam padi pada umumnya hanya sebatas untuk menjadi media alas ternak dan dibakar sia-sia untuk mengurangi jumlah tumpukan limbah tersebut, tanpa adanya pengolahan khusus agar menjadi lebih berharga. Namun pengolahan limbah dengan cara dibakar tersebut dapat mengakibatkan pencemaran udara, meningkatkan efek rumah kaca dan sangat merugikan bagi lingkungan sekitar [3]

Dilihat dari sudut pandang lain, sekam padi memiliki lebih banyak potensi baik daripada hanya sebagai limbah produk sampingan dari beras. Dari segi potensi energi, sekam padi dapat digolongkan sebagai energi alternatif dan dapat didaur ulang karena proses produksi padi akan dilakukan dengan siklus secara berulang dan terus menerus sehingga sumber daya alam sekam akan terus didapat [4]. Menurut Houston (1972) sekam memiliki kerapatan jenis (bulk density) sebesar $0,1 \mathrm{~g} / \mathrm{ml}$ atau $125 \mathrm{~kg} / \mathrm{m}^{3}$ dan nilai kalori sebesar 3300-3600 kkal/kg dengan konduktifitas panas sebesar 0,271 BTU. Dengan jumlah energi potensial tersebut jika dapat dimanfaatkan dengan metode yang tepat maka sekam layak menjadi pilihan energi alternatif pengganti bahan bakar fosil [5].

Sehingga dibutuhkan suatu pengolahan limbah yang lebih modern dengan memanfaatkan teknologiteknologi terbaru untuk menghasilkan suatu alat tepat guna yang dapat mengubah bentuk limbah sekam menjadi produk yang lebih berguna dan lebih mudah untuk diolah menjadi produk baru ataupun bahan tambahan produk lain, dan secara umum yang digunakan adalah dalam bentuk tepung. Tepung sekam diperoleh dari proses penggilingan dengan mesin penggiling. Pembuatan mesin penggiling tersebut harus dapat memenuhi kebutuhan-kebutuhan yang ada sehingga sekam dapat dimanfaatkan secara maksimal [6].

\section{Metode}

Pengambilan data dilakukan sebanyak 3 kali yaitu dengan cara membandingkan data yang telah didapat, jika memiliki selisih data yang kecil dan hasil produk dapat dilihat secara visual sesuai dengan yang diharapkan maka data tersebut dapat dianggap valid.

\section{Hasil dan Pembahasan}

Saat ini pengolahan limbah umumnya hanya dibakar sehingga mengakibatkan pencemaran udara. Sehingga perlu adanya perancangan dan pembuatan mesin penggiling yang dapat memanfaatkan sekam secara maksimal [7].

Sekam adalah produk limbah dari proses penggilingan atau penumbukan merang untuk mendapatkan beras, sekam memiliki karakteristik bentuk lapisan keras, kering, dan bersisik, memiliki massa jenis $100 \mathrm{~kg} / \mathrm{m}^{3}$ dan nilai panas 3300-3600 kkal/jam. Kandungan sekam didominasi oleh serat kasar dan karbohidrat serta sedikit protein, lemak, dan abu. Unsur dan senyawa kimia yang terdapat di sekam padi terdiri dari oksigen, silika, hidrogen dan karbon [8].

Mesin penggiling memiliki berbagai jenis mekanisme sesuai dengan karakteristik material yang akan digiling, untuk jenis material sekam dapat menggunakan jenis penggiling impact mills, attrition mills, atau tumbling mills namun pemilihan jenis penggiling juga harus mempertimbangkan skala kapasitas produksi [9, 10]. Penggiling sekam padi yang dirancang ditujukan untuk penggunaan skala rumah tangga dan mudah dioperasikan oleh masyarakat luas [11].

\section{Perumusan Konsep Desain}

Penulis menggunakan 3 variasi alternatif solusi alat dalam tabel morfologi. Tabel morfologi dapat dilihat dibawah ini.

Tabel 1. Tabel morfologi.

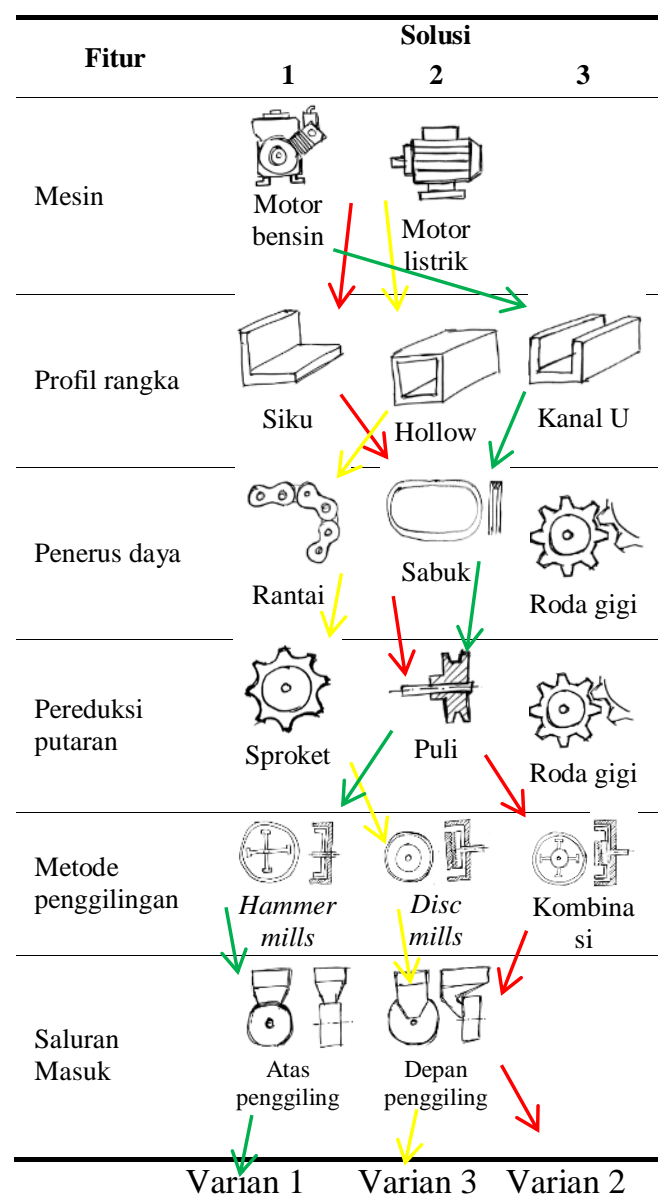

Hasil yang didapat dari 3 varian konsep dalam tabel morfologi dapat dilihat pada Gambar 1. Varian terbaik yang secara keseluruhan dapat memenuhi kriteria mendapatkan nilai 100. Tabel penilaian varian dapat dilihat pada Tabel 2 . 


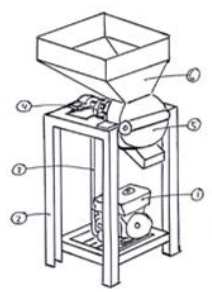

(a)

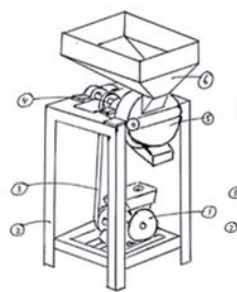

(b)
Keterangan:

1. Motor Bensin

2. Kanal U

3. Sabuk

4. Puli

5. Hammer Mills

6. Atas Penggiling
Keterangan:

1. Motor Bensin

2. Siku

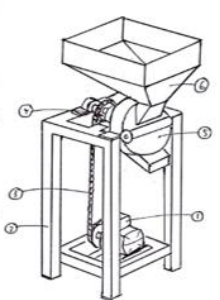

(c)

Keterangan:

1. Motor Listrik

2. Hollow

3. Rantai

4. Sproket

5.Disc Mills

5. Kombinasi

6.Depan Penggiling 6.Depan Penggiling

Gambar 1. Varian desain konsep, (a) Varian 1, (b) Varian 2, dan (c) Varian 3.

Tabel 2. Tabel penilaian varian.

\begin{tabular}{|c|c|c|c|c|}
\hline \multirow{2}{*}{ Kriteria } & \multirow{2}{*}{ Bobot } & \multicolumn{3}{|c|}{ Varian Konsep } \\
\hline & & 1 & 2 & 3 \\
\hline Desain sederhana & 0,182 & 100 & 100 & 100 \\
\hline Mudah disetel & 0,164 & 70 & 80 & 90 \\
\hline Mudah dirakit & 0,145 & 90 & 90 & 80 \\
\hline Inovatif & 0,127 & 70 & 90 & 70 \\
\hline $\begin{array}{l}\text { Pengoperasian } \\
\text { yang mudah }\end{array}$ & 0,109 & 100 & 100 & 100 \\
\hline $\begin{array}{l}\text { Mudah dalam } \\
\text { perawatan }\end{array}$ & 0,091 & 80 & 80 & 80 \\
\hline $\begin{array}{l}\text { Tidak } \\
\text { memerlukan } \\
\text { banyak ruang }\end{array}$ & 0,073 & 80 & 90 & 80 \\
\hline $\begin{array}{l}\text { Material mudah } \\
\text { didapat dipasaran }\end{array}$ & 0,054 & 90 & 90 & 70 \\
\hline $\begin{array}{l}\text { Bobot yang } \\
\text { ringan }\end{array}$ & 0,018 & 70 & 80 & 80 \\
\hline $\begin{array}{l}\text { Biaya pembuatan } \\
\text { relatif murah }\end{array}$ & 0,018 & 70 & 70 & 80 \\
\hline $\begin{array}{l}\text { Proses pembuatan } \\
\text { yang mudah }\end{array}$ & 0,018 & 70 & 70 & 80 \\
\hline Jumlah & 1 & 84,28 & 89,37 & 85,57 \\
\hline
\end{tabular}

Dari Tabel 2 tersebut diketahui urutan nilai akhir yaitu dari varian 2 dengan nilai akhir 89,37, varian 3 dengan nilai akhir 85,57, dan varian 1 dengan nilai akhir 84,28. Sehingga varian 2 dapat dikembangkan ke tahap selanjutnya. Selanjutnya melakukan permodelan varian 2 menggunakan 3D Parametric Software SolidWorks dengan hasil model dapat dilihat pada Gambar 2.

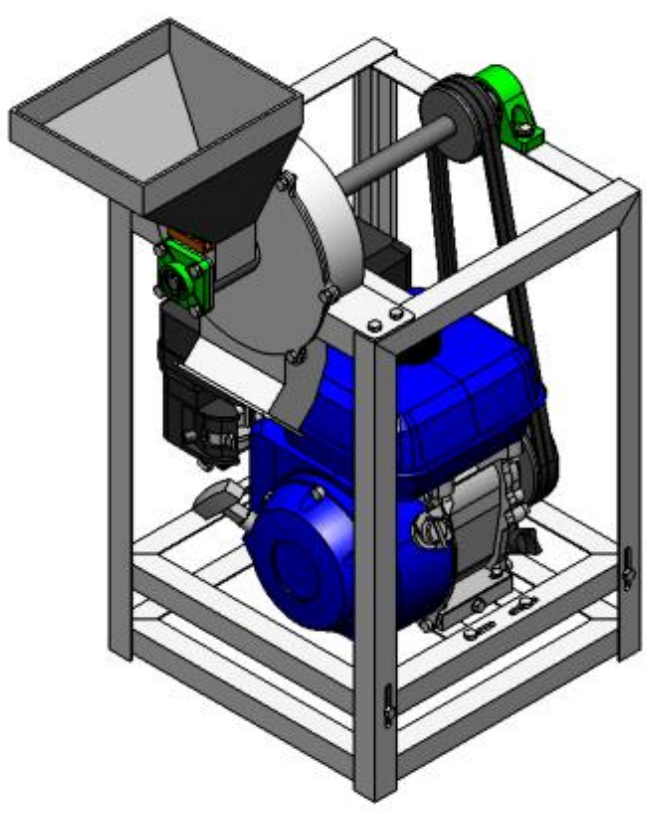

Gambar 2. Model mesin penggiling sekam padi.

Model mesin penggiling sekam padi yang dibuat memiliki desain yang telah sesuai dengan kebutuhan spesifikasi dengan dimensi yang cukup kecil dan tinggi yang dapat dijangkau mayoritas masyarakat untuk menuangkan bahan sekam padi. Untuk permodelan elemen pendukung lainnya penulis berfokus pada elemen penting menggunakan permodelan matematika untuk memastikan bahwa mesin yang telah dirancang aman untuk dibuat dan digunakan.

Mekanisme penggilingan pada mesin penggiling sekam padi ini mengadaptasi dan menggabungkan metode penggilingan hammer mills dan disc mills, sehingga penggiling dengan mekanisme kombinasi ini dapat menerapkan tiga gaya penghancur material yaitu gaya tekan, gaya tumbukan, dan gaya geser. Umumya jenis penggiling palu memiliki ruang kosong di tengahnya, dan jenis penggiling piringan memiliki ruang kosong di sisi luar penggiling, sehingga dua metode penggiling tersebut dapat digabungkan dengan posisi penggiling piringan di sisi tengah dan posisi penggiling palu di sisi luar dekat dengan wadah (casing), sehingga sekam padi yang masuk yang didorong oleh screw pengumpan dari sisi tengah dan akan digiling oleh penggiling piringan dahulu, lalu sekam yang ukurannya belum sesuai akan digiling lagi oleh penggiling palu hingga sesuai dengan ukuran penyaringnya. Untuk memahami letak komponen penggilingan kombinasi lebih jelas dapat melihat Gambar 3 berikut. 


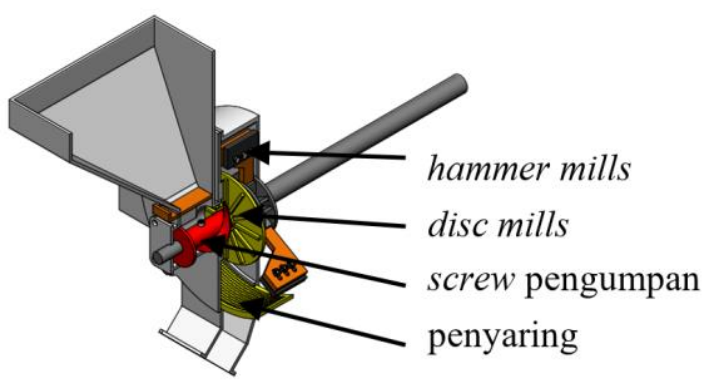

Gambar 3. Komponen penggilingan kombinasi.

Pemilihan mesin penggerak yang digunakan untuk model mesin penggiling sekam padi harus mempertimbangkan dengan spesifikasi yang telah ditentukan, sehingga penulis memilih motor bakar bensin Hyundai HDE 390 dengan spesifikasi daya 7,6 kW dan putaran $3600 \mathrm{rpm}$. Selanjutnya memilih faktor koreksi fc yang didapat dari tabel faktor koreksi daya yaitu sebesar 1,4 untuk daya rata-rata, mesin penggerak torak dengan jam kerja 8-10 jam untuk penggiling palu.

Adapun bentuk mesin penggiling sekam padi hasil rancangan yang telah dibuat dapat dilihat pada Gambar 4 berikut.

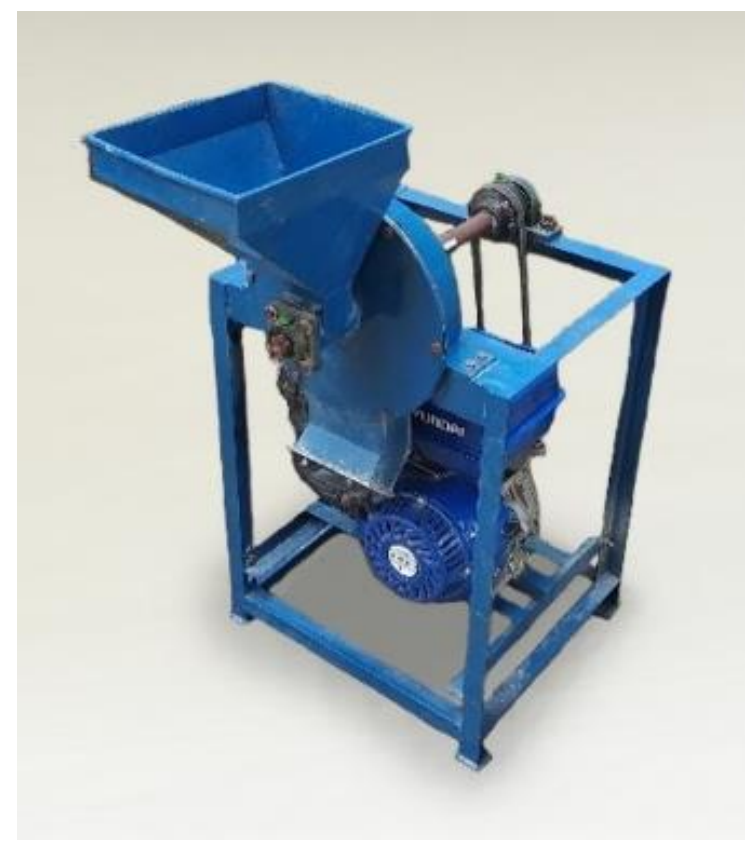

Gambar 4. Mesin penggiling sekam padi.

Hasil dari pengujian mesin penggiling sekam padi dapat dilihat pada Tabel 3 data hasil pengujian mesin penggiling sekam padi dapat dilihat di bawah ini

Tabel 3. Tabel data hasil pengujian.

\begin{tabular}{lcccc}
\hline Pengujian & $\mathbf{1}$ & $\mathbf{2}$ & $\mathbf{3}$ & $\begin{array}{c}\text { Rata- } \\
\text { rata }\end{array}$ \\
\hline Bahan masuk $(\mathrm{kg})$ & 1 & 1 & 1 & 1 \\
\hline $\begin{array}{l}\text { Produk hasil } \\
\text { penggilingan }(\mathrm{kg})\end{array}$ & 0,904 & 0,914 & 0,916 & 0,911 \\
\hline
\end{tabular}

\begin{tabular}{lcccc}
\hline $\begin{array}{l}\text { Waktu } \\
\text { penggilingan (s) }\end{array}$ & 360 & 362 & 369 & 363,67 \\
\hline $\begin{array}{l}\text { Konsumsi bahan } \\
\text { bakar(ml) }\end{array}$ & 205 & 210 & 212 & 209,00 \\
\hline $\begin{array}{l}\text { Putaran mesin } \\
\text { penggiling (RPM) }\end{array}$ & 3000 & 3000 & 3000 & 3000 \\
\hline $\begin{array}{l}\text { Sekam yang } \\
\text { berada di dalam } \\
\text { ruang penggiling } \\
\text { (kg) }\end{array}$ & 0,040 & 0,027 & 0,024 & 0,0303 \\
\hline $\begin{array}{l}\text { Ukuran lubang } \\
\text { penyaring (mesh) }\end{array}$ & 20 & 20 & 20 & 20 \\
\hline
\end{tabular}

Pengujian dilakukan menggunakan bahan sekam sebanyak $1 \mathrm{~kg}$, menggunakan lubang penyaring 0,8 $\mathrm{mm}$ atau standar mesh No. 20 dan menetapkan putaran penggiling di $3000 \mathrm{rpm}$ selama tiga kali percobaan.

Pada tahap perancangan untuk proses pemilihan variasi desain konsep didapatkan variasi terbaik yaitu variasi 2 dengan nilai 89,37 dengan spesifikasi mesin penggerak motor bensin, rangka profil siku, transmisi sabuk dan puli, mekanisme penggilingan kombinasi yaitu hammer mills dan disc mills dan saluran masuk melalui depan penggiling dan pada tahap permodelan selanjutnya mesin penggiling dirancang dalam bentuk 3D modelling dengan menggunakan software SolidWorks dan dihitung standar dimensi minimal tiap komponen sehingga mesin penggiling sekam padi memiliki dimensi tinggi $1100 \mathrm{~mm}$, panjang dan lebar $500 \mathrm{~mm}$ sampai pada pembuatan gambar teknik untuk proses pembuatan. Dalam tahap pembuatan terjadi perubahan pada saluran masuk bahan sekam yang ditambah oleh komponen screw pengumpan untuk menjamin bahan sekam dapat masuk dengan lancar ke dalam ruang penggiling. Pada proses pembuatan tersebut berlangsung selama kurang lebih 5 bulan yaitu dari dari tanggal 23 Maret sampai 8 Agustus 2018 dari target awal yaitu 2 minggu. Kemunduran target tersebut dikarenakan terdapat beberapa masalah yang penyelesaiannya terjadi dalam waktu berharihari, seperti proses pemesanan mesin penggerak motor bensin Hyundai HDE 390 yang memakan waktu lama pada proses pengirimannya, kesulitan dalam memilih metode yang tepat pada proses pemesinan untuk komponen yang memiliki jarak antar komponen lain yang terlalu dekat, dan pengerjaan komponen besar yang di luar kemampuan alat standar juga memakan waktu yang lama. Pada tahap pengujian hasil yang telah dilakukan sebanyak tiga kali percobaan dengan bahan masuk sama yaitu 1 $\mathrm{kg}$ didapatkan memiliki kualitas produk dengan kehalusan yang seragam dan sesuai dengan yang diinginkan. Untuk melihat produk hasil dari penggilingan dapat dilihat pada Gambar 5 berikut. 


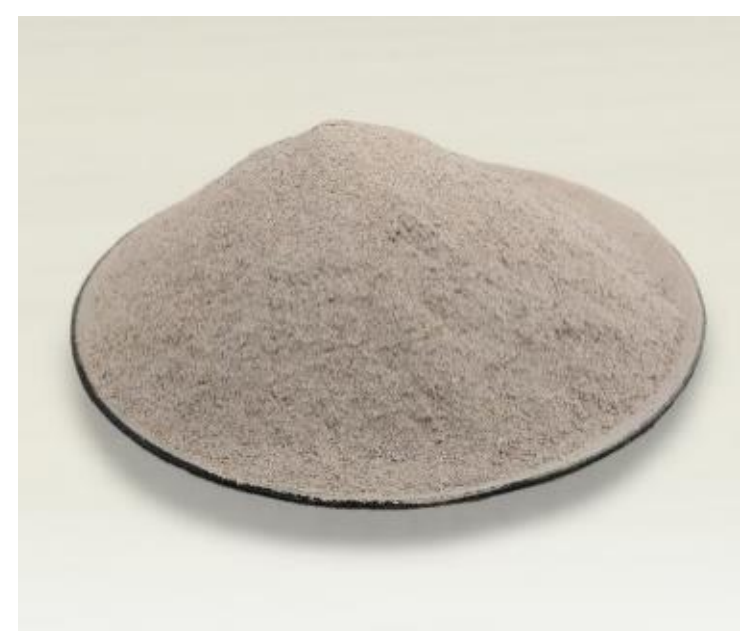

Gambar 5. Sekam padi setelah digiling.

\section{Kesimpulan}

Telah dilakukan proses perancangan dan pembuatan mesin penggiling sekam padi dengan spesifikasi dimensi tinggi $1100 \mathrm{~mm}$, panjang $500 \mathrm{~mm}$ dan lebar $500 \mathrm{~mm}$, mesin penggerak motor bensin Hyundai HDE 390 dengan daya 7,6 kW dan putaran mesin $3600 \mathrm{rpm}$, rangka profil siku $40 \mathrm{~mm}$ x $40 \mathrm{~mm}$ x $5 \mathrm{~mm}$, transmisi sabuk dan puli, mekanisme penggilingan kombinasi yaitu hammer mills yang memiliki 3 buah palu pemukul dan disc mills tipe Single Disc Attrition Mills, saluran masuk melalui depan penggiling dengan bantuan komponen screw pengumpan. Hasil analisa terbaik untuk kapasitas produksi didapat pada percobaan pertama yaitu $10 \mathrm{~kg} / \mathrm{jam}$, dan untuk konsumsi bahan bakar paling sedikit pada percobaan pertama yaitu 2,05 L/jam.

\section{Daftar Pustaka}

[1] Badan Pusat Statistik Indonesia. 2015. Produksi Padi Menurut Provinsi (ton), 1993-2015. https://www.bps.go.id/linkTableDinamis/view/i d/865. Diakses pada tanggal 3 Oktober 2017.

[2] Badan Penelitian dan Pengembangan Pertanian, Kementrian Pertanian Republik Indonesia. 2008. Sekam Padi Sebagai Sumber Energi Alternatif dalam Rumah Tangga Petani. http://www.litbang.pertanian.go.id/artikel/one/2 10/. Diakses pada tanggal 3 Oktober 2017.

[3] Balai Besar Penelitian Tanaman Padi. 2016. Klasifikasi Umur Tanaman Padi. http://bbpadi.litbang.pertanian.go.id/index.php/i nfo-berita/tahukah-anda/820/klasifikasi-umurtanaman-padi. Diakses pada tanggal 3 Oktober 2017.

[4] Sulardjo. 2013. Pemanfaatan Limbah Padi Untuk Industri. Fakultas THP UNWIDHA.Klaten. Magistra No. 84 Th. XXV.

[5] Houston, D.F. 1972. Rice Chemistry and Technology. Minnesota: American Association of Cereal Chemist, Inc. St. Paul. p. 537.
[6] Brennan, James G. 2006. Food Processing Handbook. WILEY-VCH Verlag GmbH \& Co. KGaA, Weinheim.

[7] Grist, D.H. 1972. Rice. 4th Ed. Lowe and Brydine Ltd, London.

[8] Kementrian Pertanian. 2016. ARAM-II Mengindikasikan Pasokan Beras Cukup. http://tanamanpangan.pertanian.go.id/index.php /informasi/82. Diakses pada tanggal 3 Oktober 2017.

[9] Hurts, Kenneth S. 1999. Prinsip Prinsip Perancangan Teknik. University of Hull.

[10] Alisjahbana, Sofia W. 2013. Prinsip Dasar Mekanika Struktur. Graha Ilmu.

[11] Sularso, dan K. Suga. 1991. Dasar Perencanaan dan Pemilihan Elemen Mesin. PT.Pradnya Paramita, Jakarta. 